\title{
Influence of Profitability, Tax Aggressiveness, and Institutional Ownership of Corporate Value
}

\author{
Eva Fadhilah ${ }^{1}$ \\ Syaiful $^{2}$ \\ Nyimas Wardatul Afiqoh ${ }^{3}$ \\ 1,2,3,4 Universitas Muhammadiyah Gresik Indonesia \\ 1 evafadhilah19@gmail.com \\ ${ }^{2}$ syaiful@umg.ac.id \\ 33afiqohnyimas@gmail.com
}

\begin{abstract}
ABSTRAK
Penelitian ini bertujuan untuk mengetahui pengaruh profitabilitas, agresivitas pajak, dan kepemilikan institusional terhadap nilai perusahaan. Penelitian ini menggunakan metode kasual dengan mengambil data sekunder. Pemilihan sampel menggunakan metode purposive sampling. Dari kriteria yang telah ditentukan diperoleh sampel sebanyak 43 perusahaan dengan masa studi 2015-2017, sehingga total pengamatan adalah 129. Analisis data menggunakan analisis regresi linier berganda. Hasil penelitian menunjukkan bahwa profitabilitas dan agresivitas pajak memiliki pengaruh terhadap nilai perusahaan. Tetapi kepemilikan institusional tidak memiliki pengaruh terhadap nilai perusahaan.
\end{abstract}

Kata Kunci : Profitabilitas, agresivitas pajak, kepemilikan institusional

\section{ABSTRACT}

The research aimed to determine the effect of profitability, tax aggressiveness, and institutional ownership to the firm value. This research was used a casual method by taking secondary data. The selection of sample used purposive sampling method. From the predetermined criteria obtained a sample of 43 companies with study period of 2015-2017, so total of observation is 129. Analyzing of data was used multiple linear regression analyzed. The results shows that the profitability and tax aggressiveness have influence to the firm value. But the institutional ownership does not have influence to the firm value.

Keywords: Profitability, Tax Aggressiveness, Institutional Ownership

\section{INTRODUCTION}

Increasing company value is one of the longterm goals that must be achieved by the company. Company value according to Keown et al (2010: 35) is the market value of a company's debt and equity. The company's value is very influential for several parties. Starting from the owner of the company, shareholders, stakeholders, investors to the wider community.

Profitability is one factor in measuring company value. The value of the company itself can be seen from its financial ratios. The financial ratios used to measure profitability are
Return On Assets (ROA). Return On Assets is a ratio that shows the rate of return or return on total assets of a company.

Profitability is one indicator that affects the value of a company. The value of the company is considered good if the company's profitability has increased. With the high profits earned by a company, this will certainly affect the tax burden that must be incurred by the company. Basic Tax Imposition (DPP) is the taxable income of the income recipient taxpayer. The amount of taxable income for corporate taxpayers is calculated as net income. Based on 
the 2009 KUP Law article 1 paragraph 1 tax is a mandatory contribution to the state owed by individuals or entities that are coercive based on the Law, with no direct compensation and used for the country's needs for the greatest prosperity of the people. Taxes become one of the biggest revenues for the country.

The higher the profits obtained by the company, the greater the burden of tax paid. The company is one of the taxpayers who has the obligation to pay taxes, the amount of tax that must be paid by the company can be seen from the net profit obtained. The high tax payable which causes some companies to minimize the tax burden owed. Tax aggressiveness is one way can do companies. According to Lanis and Richardson (2011) in Sari, et al., (2016) tax aggressiveness is a desire by actions to minimize the tax burden legally, illegally, or both.

According to Haruman (2008) in the process of increasing the value of the company the company manager has other goals and interests that conflict with the company's goals, and often ignores the interests of shareholders. These differences in interests have resulted in agency conflict. Ways to minimize agency conflict include the existence of share ownership by management and by institutions.

The ownership structure that influences company value, one of which is institutional ownership. Institutional ownership usually acts as a company supervisor. High institutional ownership can monitor management. The higher the institutional ownership, the greater the supervision given to management. The supervision is expected to minimize the deviations that occur on the part of management which can reduce the value of the company (Susanti \& Mildawati, 2014).

This study aims to prove that:

1. To analyze whether there is an effect of profitability on company value partially and simultaneously on manufacturing companies on the Stock Exchange in the 2015-2017 period.
2. To analyze whether there is a partial and simultaneous influence of tax aggressiveness on company value in manufacturing companies on the Stock Exchange in the 2015-2017 period.

3. To analyze whether there is a partial and simultaneous influence of institutional ownership on firm value in manufacturing companies on the Stock Exchange in the 2015-2017 period.

\section{LITERATURE REVIEW}

\section{Signal Theory}

Signal theory is a sign of the company in providing instructions to users of financial statements. According to Brigham and Houston (2001) in (Ferina, et al., 2015) signal is an action taken by company management that provides instructions for investors about how management views the prospects of a company.

\section{Agency Theory}

Agency relationships are one or more people who are called principals using the services of other individuals or organizations called agents who are given the authority to make the best decisions for the principal. This is done because the principal (shareholder) wants to know all the information and management activities related to his investment in the company by looking at the agent's responsibility report (management). From this report it will be known how the company's management performance.

\section{Company Value}

Company value is a condition that has been achieved or wants to be achieved by a company as an illustration of public trust in the company after going through a process of activities for several years. Since the company was founded until now.

\section{Profitability}

Profitability is the company's ability to obtain net profit (Artimaharani \& Bambang, 2015). Investors who invest shares in companies with 
the aim of getting returns consisting of yields and capital gains. So that the greater the profits earned by the company, the greater the return expected by investors. and that makes the company's value better.

\section{Tax Aggressiveness}

According to Lanis and Richardson (2011) in (Sari et al., 2016) defines tax aggressiveness as a desire and action to minimize the tax burden by legal, illegal, or both. The definition of tax aggressiveness according to Hlaing (2012) in (Sari et al., 2016) is as a coverage of all tax planning activities that companies will undertake in reducing effective tax rates, in accordance with the definition of tax avoidance expressed by Dryeng, et al (2008). The tax aggressiveness is expected to increase company profits. The higher the company's profit the higher the company's value.

\section{Institutional Ownership}

Institutional ownership is the ownership of company shares owned by an institution or institution. Institutional ownership has an important role in overseeing management with the existence of institutional ownership can encourage the improvement of more optimal supervision. The supervision is expected to provide prosperity for shareholders, the influence of institutional ownership as a supervisory agent is suppressed through their sizable investment in the capital market. With high institutional ownership, it will lead to greater oversight efforts by institutional investors so that it can hinder behavior opportunistic managers (Susanti \& Mildawati, 2014).

\section{METHODE}

This study uses a quantitative approach, namely research using numbers, processed data, SPSS used in this study in the form of variables that can be measured by hypotheses and theories. The location was done in this study is in the Indonesia Stock Exchange (IDX), which presents a financial report on the official website www.idx.co.id. The population in this study are all manufacturing companies listed on the Indonesia Stock Exchange. The sample in this study uses purposive sampling, which is a sampling method based on certain considerations and criteria. The criteria used are:

1. Manufacturing companies that have complete financial statements in the period 2015-2017.

2. Manufacturing companies that have financial data related to research variables.

3. Manufacturing companies that do not show negative profits.

4. The company publishes annual financial statements on the company's website and the IDX website in 2015-2017 which are stated in Rupiah (IDR).

The type of data in this study uses documentary data because this research comes from the financial statements of companies listed on the Indonesia Stock Exchange (BEI) for the 2015-2017 period. While the data source of this study uses secondary data sources. Secondary data sources are data created by other parties and researchers only record without managing the data. This data is usually in the form of reports made by other parties where the data is taken at the Indonesia Stock Exchange (IDX).

Data retrieval technique using documentation technique to retrieve data based scientific journals, and the financial statements of the companies listed in Indonesia Stock Exchange (BEI) in the period from 2015 to 2017 through the website www.idx.co.id.

The operational definition of a variable is a definition given to the variable to provide information to itself or to provide an operation that is needed to test the hypothesis that has been proposed, so the variable under study needs to take measurements. Operational Definition Variables will be explained as follows: 


\section{Dependent Variable (Y)}

The value of the company is a calculation of the price per share divided by the book value per share. Every company owner will always show potential investors, the company's Price Book Value (PBV). This ratio is used to measure the stock value performance of a company (Repi et al., 2016).

\section{Independent Variable (X)}

The independent variables in this study are Profitability, Tax Aggressiveness and Institutional Ownership,

\section{Profitability}

Return on Assets (ROA) is a ratio used to measure the profits of a company (Artimaharani \& Bambang, 2015). Return On Assets can be seen by dividing net income after tax by the total assets owned by the company. In addition, ROA can provide a better measure of company profitability because it can see the effectiveness of management in using assets to obtain revenue. Return On Assets can be calculated using the following formula:

$\mathrm{ROA}=$ Net profit after tax/Total assets

\section{Tax Aggressiveness}

Tax Aggressiveness is an action taken by the Taxpayer to reduce the tax costs. The measurement of tax aggressiveness uses the ETR (Effective Tax Rate) which can be calculated by dividing the company's total tax burden with profit before income tax (Sidanti \& Cornaylis, 2018). Can be formulated, namely:

Effective tax rate $=$ Tax burden $/$ Net profit before $\operatorname{tax}$

\section{Institutional ownership}

Institutionalownership is a share of a company owned by an institution or institution. Institutional ownership, namely shares owned by other companies divided by the total number of shares outstanding. Then the formula used is:
Institutional ownership $=$ shares owned by other institutions/Total Number of outstanding shares

\section{RESULTS AND DISCUSSION}

\section{The Overview of Research}

The Objects Objects used in this study are all manufacturing companies listed on the Indonesia Stock Exchange (BEI) in 2015-2017. In this study using secondary data in the form of company financial statements. Data obtained from the website www.idx.co.id is known that there were 154 manufacturing companies listed on the Indonesia Stock Exchange in 2015-2017.

\section{The Profitability}

Return on Asset (ROA) maximum three years in a row is owned by UNVR (PT Unilever Indonesia Tbk), with the highest value achieved in 2016 of 0.38 . The high value of profitability calculated using the ROA ratio at PT Unilever Indonesia Tbk in 2016 is a new history for PT Unilever Indonesia Tbk by achieving net sales of more than Rp40,000 billion (40 trillion) and the net profit earned is close to Rp6,400 billion (6.4 trillion) or grew by $9.7 \%$. The figure obtained by PT Unilever Indonesia Tbk is the result of continuing consistency in creating innovation and building company profitability. While the lowest for three consecutive years is RICY (PT Ricky Putra Globalindo Tbk), which is 0.01. Although PT Ricky Putra Globalindo Tbk experienced growth profitability the same for three years in a row, net sales in 2017 of PT Ricky Putra Globalindo Tbk amounted to 1.60 trillion, up $31 \%$ compared to the previous period, where the net profit generated in 2017 amounted to 16.5 billion, up $18 \%$ compared to 2016 which amounted to 14 billion.

\section{Tax Aggressiveness}

Based on the calculation of Effective Tax Rate (ETR) in 2017 owned by AMFG (PT Asahimas Flat Glass Tbk) of 0.39. Profits obtained by PT Asahimas Flat Glass Tbk decreased by Rp 221 billion (85\%) from Rp260 billion in 2016 to $\mathrm{Rp}$ 39 billion in 2017. A decrease in operating profit and an increase income tax expense in 
2017 led to PT Asahimas Flat Glass profit Tbk has decreased. Even though PT Asahimas Flat Glass Tbk showed a figure of 0.39 , the company allegedly did not carry out tax aggressiveness. While the lowest is owned by KBLM (PT Kalbelindo Murni Tbk) of 0.01 in 2017, allegedly carrying out tax aggressiveness. This can be seen from the deferred tax expense of PT Kalbelindo Murni Tbk, which amounted to Rp9.3 billion, down $38.29 \%$ compared to the position at the end of 2016 which amounted to Rp15.2 billion. Whereas the profit before tax obtained by PT Kalbelindo Murni Tbk in 2017 was IDR 44.5 billion, or an increase of $29.02 \%$ compared to the 2016 profit before tax of IDR34.5 billion.

\section{Institutional Ownership}

Based on the calculation in Appendix 2 shows that the largest institutional ownership owned by TALF (PT Tunas Alfin Tbk) is 0.99 in three consecutive years, this is due to the number of shares owned by the same institution for three consecutive years with the number of shares outstanding is around 1.3 billion shares outstanding where only $0.01 \%$ of the shares are circulating in the community. While the lowest is owned by ARNA (PT Arwana Citramulia Tbk.) Of 0.14 in 2016 and 2017. The number of shares outstanding is around 7.3 billion outstanding shares in which management ownership is higher than institutional ownership of $37 \%$ while the remaining $49 \%$ is owned by the public.

\section{Company Value}

Based on the calculation in appendix 2 shows that the largest company value owned by UNVR (PT Unilever Indonesia Tbk) was 82.44 in 2017. In 2017 PT Unilever Indonesia Tbk had a very sharp increase in share prices compared to 2016. Of course this is supported with innovations and investments that continue to be made and developed in accordance with the current economic situation so that the value of the company obtained has increased. While the lowest owned by RICY (PT Ricky Putra
Globalindo Tbk) amounted to 0.22 in 2017. Due to economic and business conditions that are still less conducive for PT Ricky Putra Globalindo Tbk of course this also affects the price of a share which has decreased every quarter. The fall in the price of a share also affects the value of the company which also experienced a decline.

\section{Data Analysis \\ Classical Assumption Test Normality}

Test Data normality test is used to see whether the data used in research is normally distributed or not. In this study the results of the normality test are concluded by looking at the normal probability plot. The first test conducted on 129 companies showed that the plot results were not good because the plot did not follow a diagonal line so that it had to dispose of the outlier data. After the outlier data has been removed, the original data 129 becomes 126 . The normality test results are obtained as follows:

\section{Figure 1 : Normality Test}

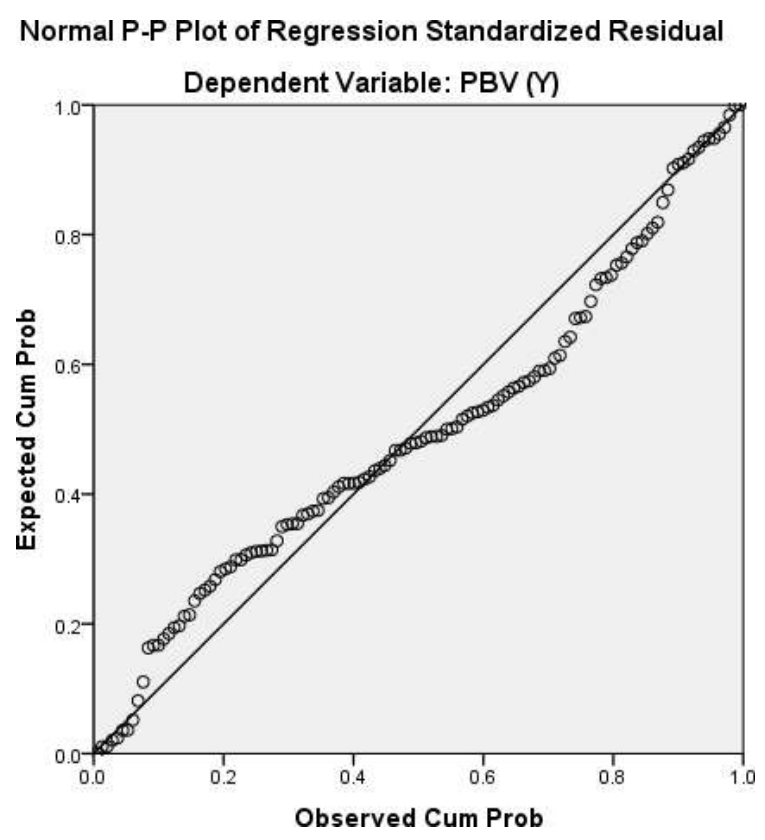

The normality test results using the normal probability plot in Figure 1 above, it is known that the SPSS output results show that the plot is aligned with a diagonal line indicating that 
the residual data from early studies with normal distribution or meeting normality assumptions.

\section{Multicollinearity Test}

The multicollinearity test aims to test whether or not there is a relationship between several independent variables in the regression model. Multicollinearity is a state in which there is a relationship between one independent variable (linear) which is linear with other variables. Multikolinieritas test results can be seen in the following table:

Table 1: Multicollinearity Test

\begin{tabular}{|c|c|c|c|c|c|c|c|c|}
\hline \multirow{2}{*}{\multicolumn{2}{|c|}{ Madel }} & \multicolumn{2}{|c|}{$\begin{array}{l}\text { Unstandandized } \\
\text { Coefficients }\end{array}$} & \multirow{2}{*}{\begin{tabular}{|c|}
$\begin{array}{c}\text { Standandized } \\
\text { Coefficients }\end{array}$ \\
Betz
\end{tabular}} & \multirow[b]{2}{*}{ T } & \multirow[b]{2}{*}{ Siz } & \multicolumn{2}{|c|}{$\begin{array}{l}\text { Collineanity } \\
\text { Sertistics }\end{array}$} \\
\hline & & B & Ssd Erros & & & & Tolennse & VII \\
\hline \multirow[t]{4}{*}{1} & (Constant) & -1501 & 823 & & -1.824 & 077 & & \\
\hline & $\mathrm{BOA}$ & $31 \cos$ & 2617 & .756 & 11.346 & 000 & 908 & 1.101 \\
\hline & EIR & 3.738 & 1.866 & .127 & 2003 & 047 & 917 & 1.091 \\
\hline & KI & 575 & .808 & .044 & .711 & .478 & 956 & 1.046 \\
\hline
\end{tabular}

A regression model can be declared to pass the multicollinearity test if it has a tolerance value above 0.1 and a VIF value below the number 10 . From table 1 it can be seen that all independent variables in this study have a tolerance value above 0.1 and also have a VIF value below the number 10. It can be concluded that in this regression model multicollinearity does not occur.

\section{Heteroskedasticity Test}

Heteroskedasticity Test aims to show that the variance of variables is not the same for all types of observations. Here are the results of the heteroskedasticity test:

\section{Figure 2: Heteroskedasticity Test}

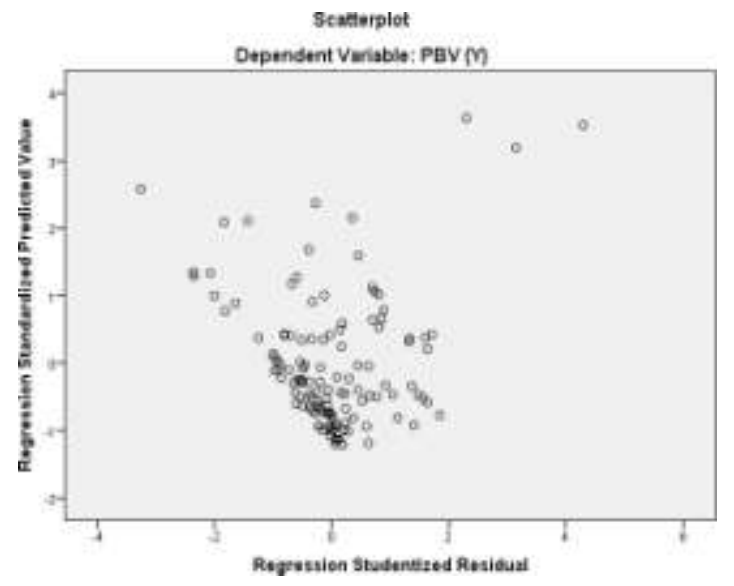

Based on the results of the heteroskedasticity test using the scatterplot image pattern produced in Figure 2, it shows that the pattern of the scattered data indicates that the regression model is free from heteroskedasticity.

\section{Autocorrelation}

Test The autocorrelation test aims to test whether in the regression model there is a correlation between confounding errors in the $t$ period and confounding errors in the $\mathrm{t}-1$ period or before. The autocorrelation test results can be seen in the following table:

\section{Table 2: Autocorrelation test}

\begin{tabular}{|l|r|r|r|r|r|}
\hline Model & R & $\begin{array}{c}\text { R } \\
\text { Square }\end{array}$ & $\begin{array}{c}\text { Adjusted R } \\
\text { Square }\end{array}$ & $\begin{array}{c}\text { Std. Error of the } \\
\text { Estimate }\end{array}$ & $\begin{array}{c}\text { Durbin- } \\
\text { Watson }\end{array}$ \\
\hline 1 & $.741^{2}$ & .548 & .537 & 1.74208 & 2.012 \\
\hline
\end{tabular}

Based on the results of the calculated DW value in table 4.8 obtained for 2012; while the size of the DW-table for samples totaling 126 and 3 independent variables produced that $\mathrm{du}$ (outer limit $)=1.7582$ and dl (inner limit) $=1.6608 ; 4$ $\mathrm{dl}=2.3392$ and $4-\mathrm{du}=2.2418$. from these results indicate that the DW-test lies in the area of absence of autocorrelation because it meets the criteria that $\mathrm{du}<\mathrm{dw}<4-\mathrm{du}$ is $1.7582<2.012$ $<2.2418$.

\section{Multiple Linear Regression Test}

Multiple linear regression is used to determine the effect of the independent variables on the dependent variable. The regression equation for this study is as follows:

Table 3: Multiple Linear Regression Test

\begin{tabular}{|c|c|c|c|c|c|c|}
\hline \multirow{2}{*}{\multicolumn{2}{|c|}{ Model }} & \multicolumn{2}{|c|}{$\begin{array}{l}\text { Unstandardized } \\
\text { Coefficientı }\end{array}$} & \multirow{2}{*}{$\begin{array}{c}\begin{array}{c}\text { Standardized } \\
\text { Coeffieients }\end{array} \\
\text { Beta }\end{array}$} & \multirow[b]{2}{*}{$t$} & \multirow[b]{2}{*}{ Sig. } \\
\hline & & B & Stal Error & & & \\
\hline \multirow[t]{4}{*}{1} & (Conitant) & -1.501 & 823 & & -1.824 & .071 \\
\hline & ROA & 31.005 & 2.617 & .756 & 11.846 & .000 \\
\hline & ETR & 3.738 & 1.866 & .127 & 2.003 & .047 \\
\hline & $\mathrm{KI}$ & .575 & .808 & .044 & .711 & .478 \\
\hline
\end{tabular}

Based on the above table multiple linear regression equation in research as follows: 
$\mathrm{PBV}=-1,501+31,005 \mathrm{ROA}+3,738 \mathrm{ETR}+$ $0,575 \mathrm{KI}+\varepsilon$

Based on the regression equation each constants will be explained and the regression coefficients of the four variables as follows: A

1. Constant of $-1,501$ states if the regression coefficient of the independent variable in the regression equation equal to 0 or a constant value of $-1,501$.

2. The regression coefficient value of ROA 31.005 that if there is a change in ROA then one unit and will increase PBV by 31,005 .

3. ETR regression coefficient value is 3,738 that if there is a change in ETR then one unit will increase PBV by 3,738 .

4. The value of the regression coefficient KI 0.575 that if there is a change in KI then one unit will increase PBV by 0.575 .

\section{Hypothesis Testing}

\section{Determination Coefficient Test}

Sugiyono's(2011: 278) states that the coefficient of determination can be seen in the value of Adjusted R Square which shows how much the independent variable can explain the independent variable. The results of the calculation of the coefficient of determination of this study can be seen in the following table 4 :

Table 4: Determination Coefficient Test

\begin{tabular}{|l|r|r|r|r|r|}
\hline Model & R & $\begin{array}{c}\text { R } \\
\text { Square }\end{array}$ & $\begin{array}{c}\text { Adjusted R } \\
\text { Square }\end{array}$ & $\begin{array}{c}\text { Std. Error of the } \\
\text { Estimate }\end{array}$ & $\begin{array}{c}\text { Duroin- } \\
\text { Watson }\end{array}$ \\
\hline 1 & $.741^{2}$ & .548 & 537 & 1.74208 & 2.012 \\
\hline
\end{tabular}

Based on SPSS output results show that the obtained value of the coefficient of determination (R2) in the manufacturing companies listed in Indonesia Stock Exchange during 2015-2017 amounted to 0537. this shows that the effect of profitability, tax aggressiveness, and institutional ownership on firm value that can be explained by this equation model is $53.7 \%$ while the remaining $46.3 \%$ is influenced by other factors.

\section{F Test}

The F statistical test basically shows whether all the independent variables entered in the model have a joint influence on the dependent variable. The results of the F test calculation can be seen in the following table:

Table 5: F Test

\begin{tabular}{|c|c|c|c|c|c|c|}
\hline Model & & $\begin{array}{l}\text { Sum of } \\
\text { Squates }\end{array}$ & Dt & Mean Square & F & Sig. \\
\hline \multirow[t]{3}{*}{1} & Regression & 449.707 & 3 & 149.902 & 49.393 & $.000^{\circ}$ \\
\hline & Residual & 370.253 & 122 & 3.035 & & \\
\hline & Total & $\$ 19.960$ & 125 & & & \\
\hline
\end{tabular}

From the regression results it can be seen that together the independent variables (profitability, tax aggressiveness, and institutional ownership) have a significant influence on the dependent variable, namely the value of the company. This can be proven from the calculated $\mathrm{F}$ value of 49,393 which is much higher than the F table of 2.6789127. a probability value of 0,000 which is much smaller than the significance level used is $5 \%$, then the regression model can be used to predict the value of the company or it can be shown that the profitability, tax aggressiveness, and institutional ownership variables simultaneously (simultaneously) affect the value of the company.

\section{$t$ test}

$t$ test was used to test the effect of each of the independent variables used in this study partially. $T$ Test results can be seen in the table as follows:

Table 6: $t$ test

\begin{tabular}{|c|c|c|c|c|c|c|}
\hline \multirow{2}{*}{\multicolumn{2}{|c|}{ Model }} & \multicolumn{2}{|c|}{$\begin{array}{l}\text { Unstandandized } \\
\text { Coefficients }\end{array}$} & \multirow{2}{*}{$\begin{array}{c}\begin{array}{c}\text { Standardized } \\
\text { Coefficients }\end{array} \\
\text { Beta }\end{array}$} & \multirow[b]{2}{*}{$t$} & \multirow[b]{2}{*}{ Sig. } \\
\hline & & B & Std. Error & & & \\
\hline \multirow[t]{4}{*}{$\pi$} & (Constant) & -1.501 & 823 & & -1.824 & .071 \\
\hline & ROA & 31.005 & 2.617 & .756 & 11.846 & .000 \\
\hline & ETR & 3.738 & 1.866 & .127 & 2.003 & .047 \\
\hline & $\mathrm{KI}$ & 575 & .808 & .044 & .711 & .478 \\
\hline
\end{tabular}

Based on $t$ test results are shown in Table 6 shows that the influence of the independent variables on the dependent variable is as follows: 


\section{Profitability Relationship to Firm Value}

Hypothesis 1 (H1) testing shows the t-count compared to the t-table that is $11,846 \geqslant 1.9796$ and a significant value of $0.000 \leqslant 0.05$. that this shows that the profitability variable has a positive and significant effect on firm value. Then it can be concluded that the profitability of manufacturing companies in 2015-2017 affect the value of the company. This means that the results of testing this hypothesis indicate that the profitability of the manufacturing companies studied partially affects the firm's value. This value indicates that the higher the profitability, the higher the value of the company. Conversely the lower the profitability, the lower the value of the company. Profitability illustrates a company's ability to earn profits to control all operational and non-operational costs. Companies that are able to generate large profits tend to be more trusted by investors (Artimaharani \& Bambang, 2015). Some investors tend to value companies based on the profits obtained, such as PT Unilever Indonesia Tbk, which has stable or tends to increase profits. In a study of manufacturing companies in 2015-2017 the average showed an increase in profitability. The increase in profitability obtained by the company is one of the company's goals to attract investors. So the increase in profitability can also make the company's value increase. This study is consistent with the research of Artimaharani \& Bambang (2015) which shows the effect of profitability on firm value. In the research of Artimaharani \& Bambang (2015), using a sample of insurance companies during the 2008-2014 period with a beta value of 0.38 .

\section{Relationship of Tax Aggressiveness to Firm Value}

Hypothesis 2 (H2) test shows t-count compared to $\mathrm{t}$-table that is $2.003 \geqslant 1.9796$ and a significant value of $0.047 \leqslant 0.05$. that this shows that the tax aggressiveness variable has a positive and significant effect on firm value. then it can be concluded that the aggressiveness of manufacturing company tax in 2015-2017 affects the value of the company. This means that the results of hypothesis testing indicate that the tax aggressiveness of manufacturing companies has a significant effect on firm value. This shows that there are still many manufacturing companies that take tax aggressiveness measures so that the company's tax burden is not so high that it does not reduce the company's profits. So in this research it is suspected that there are still a lot of tax aggressiveness done by manufacturing companies to reduce the tax burden that must be paid. The results of this study are consistent with research by Jonathan and Adeyani (2015) which states that tax avoidance influences company value. However, this study is different from the research revealed by Torihosan \& Anita (2016) with a sample of manufacturing companies in the 2011-2014 period, the results of the study stated that there was no significant effect of tax aggressiveness on firm value. This can happen because according to Torihosan \& Anita (2016) the tendency of investors to invest does not pay too much attention to how much tax the company pays. Investors prefer to invest in companies whose profits are stable or high.

\section{The Relationship of Institutional Ownership to Firm Value}

Hypothesis 3 (H3) testing shows the t-count compared to the $\mathrm{t}$-table that is $0.711 \leqslant 1.9796$ and a significant value that is $0.478 \geqslant 0.05$. that this shows that institutional ownership has a positive but not significant effect on firm value. Then it can be concluded that the institutional ownership of manufacturing companies in 2015-2017 does not affect the value of the company. This means that the results of hypothesis testing indicate that partially the ratio of institutional ownership structure of manufacturing companies has no effect on firm value. Because of the large number of shareholders, it is not necessarily effective in overseeing the behavior of managers in the company, so ownership by institutions cannot be used as a supervisory 
mechanism for company managers to increase company value.

The results of this test are in accordance with the research of Artimaharani \& Bambang (2015) which shows a beta value of 0.02 with a significant value of 0.90 which is greater than the probability value of 0.05 . Which means that the study states that institutional ownership has no significant effect on firm value. This test is different from the research of Fauzan et al (2012) with the sample used, namely insurance companies for the period 2006-2010 which states that institutional ownership affects the value of the company. This means that it can be concluded that the structure of institutional ownership will partially increase the value of the company if the value of institutional ownership also rises, and vice versa. If the ownership structure partially reduces the value of the company if the value of the institutional ownership structure also decreases.

\section{CONCLUSION}

This study aims to look at the effect between profitability, tax aggressiveness, and institutional ownership on firm value. Of all the variables studied, there are two variables that have a significant effect on firm value, namely profitability and tax aggressiveness. In a study conducted on manufacturing companies in 2015-2017, several companies showed an increase in profitability that affected the value of the company. High profitability in manufacturing companies also affects companies to carry out tax aggressiveness. Tax aggressiveness is done to minimize the tax burden that must be paid when the company gets high profits, this also has an impact on the company's value. Tax aggressiveness affects the value of the company because when the company gets high profits and tax aggressiveness of course the profits of manufacturing companies will not decline. So that the value of the company will also not decrease. Another variable that does not affect the firm's value is institutional ownership. Institutional ownership does not affect the value of the company because institutional ownership is still low in manufacturing companies. The low level of institutional ownership also shows that supervision of company management is still low.

\section{REFERENCES}

Artimaharani, A., \& Bambang, S. (2015). Pengaruh Struktur Kepemilikan, Early Warning System Kinerja dan Profitabilitas Terhadap Nilai Perusahaan. Jurnal Ilmu \& Riset Akuntansi, 4(12), 120.

Dwi, S., \& Ambarwati, A. (2015). Dampak struktur kepemilikan, financial leverage, board director terhadap nilai perusahaan. Jurnal Keuangan Dan Perbankan, 19(3), 391-399.

Fauzan, f., Nadirsyah, dan M. Arfan. (2012). Pengaruh Struktur Kepemilikan dan Kinerja Keuangan Early Warning System Terhadap Nilai Perusahaan. Jurnal Akuntansi Pascasarjana universitass Syiah Kuala 2(1); 64-75.

Ferina, I. S., Tjandrakirana, R., \& Ismail, I. (2015). Pengaruh Kebijakan Dividen, Kebijakan Hutang, dan Profitabilitas Terhadap Nilai Perusahaan (Studi Pada Perusahaan Pertambangan yang terdaftar di BEI Periode 2009-2013). Jurnal Akuntanika, 2(1), 52-66.

Ghozali, Imam. 2005. Aplikasi Analisis Multivariate dengan SPSS. Semarang: Badan Penerbit Universitas Diponegoro.

Ghozali, Imam. 2011. Aplikasi Analisis Multivariate dengan Program SPSS. Semarang: Badan Penerbit Universitas Diponegoro.

Ghozali, Imam. 2012. Aplikasi Analisis Multivariate dengan Program IBM SPSS. 
Semarang: Badan Penerbit Universitas Diponegoro.

Haruman, T. (2008). Pengaruh Struktur Kepemilikan Terhadap Keputusan Pendanaan.

National Conference Onmanagement Research, (November), 1-20.

Hidayanti, A. N., \& Laksito, H. (2013). Pengaruh Antara Kepemilikan Keluarga dan Corporate Governance Terhadap Tindakan Pajak Agresif. Diponegoro Journal of Accounting, 2(2), 1-12.

Jhonatan, \& Tandean, Vivi Adeyani (2015). Pengaruh Tax Avoidance Terhadap Nilai Perusahaan Dengan Profitabilitas Sebagai Variabel Pemoderasi. ISBN: 978-9793649-96-2.

Mai, M. U. (2015). Corporate Governance dan Interdependensi antara Leverage, Profitabilitas, serta Kebijakan Dividen dalam Mencapai Nilai Perusahaan. Jurnal Keuangan Dan Perbankan, 19(2), 213225.

Keown, Arthur J., David F. Scott, John D. Martin, J. William Petty. 2010. Manajemen Keuangan: Prinsip dan Penerapan. Jakarta Barat: Indeks.

Repi, S., Murni, S., \& Adare, D. (2016). FaktorFaktor Yang Mempengaruhi Nilai Perusahaan Subsektor Perbankan Pada Bei Dalam Menghadapi Mea. Jurnal EMBA, 4(1), 181-191.

Sari, N. W., Pratomo, D., Yudowati, S. P., Telkom, U., Laba, M., Accrual, D., \& Difference, B. T. (2016). Pengaruh manajemen laba terhadap agresivitas pajak. E- Proceeding of Management, 3(2), 1530-1535.
Sidanti, H., \& Cornaylis, V. (2018). Pengaruh Agresivitas Pajak terhadap Nilai Perusahaan dengan Profitabilitas sebagai Variabel Moderasi (Studi Empiris Perusahaan Manufaktur Sektor Pertanian Subsektor Perkebunan di BEI). Jurnal Akuntansi, 1(2), 201-210.

Susanti, R., \& Mildawati, T. (2014). Pengaruh Kepemilikan Manajemen, Kepemilikan Institusional, Dan Corporate Social Responsibility Terhadap Nilai Perusahaan. Jurnal Ilmu \& Riset Akuntansi, 3(1), 1-86.

Tarihosan, Anita (2016). Pengaruh Penghindaran pajak dan Leverage Terhadap Nilai Perusahaan Dengan Transparansi Perusahaaan Sebagai Variabel Moderasi. Jurnal Wira Ekonomi Mikroskil, 6(2), 1-15.

Undang-Undang Republik Indonesia, Nomor 16 Tahun 2009 Tentang Perubahan Atas Undang-undang Nomor 16 Tahun 1983 Tentang Ketenuan Umum dan Tata Cara Perpajakan.

Wening, K. 2009. Pengaruh Kepemilikan Institusional Terhadap Kinerja Keuangan Perusahaan. Jakarta. 